\title{
PERUBAHAN KARAKTERISTIK FISIKOKIMIA, HIDROFOBISITAS DAN KRISTALINITAS PADA PATI JAGUNG VARIETAS BISI-18 TERASETILASI
}

\section{Changes in Characteristics of Physicochemical, Hydrophobicity, and Crystallinity in Corn Starch Acetylation}

\author{
Nita Maria Rosiana ${ }^{1 *}$, Eni Harmayani2 ${ }^{2}$ Yudi Pranoto ${ }^{2}$ \\ ${ }^{1}$ Program Studi Gizi Klinik - Jurusan Kesehatan - Politeknik Negeri Jember \\ Jl. Mastrip No. 164 - Jember 68121 \\ 2Program Studi Teknologi Pangan dan Hasil Pertanian, Fakultas Teknologi Pertanian, \\ Universitas Gadjah Mada \\ Jl. Flora No. 1 - Yogyakarta 55281 \\ *Penulis Korespondensi, email: nita.maria.r@polije.ac.id
}

\begin{abstract}
ABSTRAK
Jagung merupakan salah satu komoditas pertanian yang berpotensi besar untuk dikembangkan secara komersial. Cookies yang dibuat dari 100\% tepung jagung mengakibatkan penerimaan konsumen yang menurun karena tekstur cookies yang keras. Kekerasan pada cookies dari jagung dapat pula disebabkan oleh kemampuan pati dalam mengikat air dan lemak yang rendah serta struktur pati yang kompak. Salah satu metode modifikasi pati yang digunakan untuk memperbaiki sifat pati adalah asetilasi. Persyaratan derajat asetilasi pada pati yang dapat digunakan untuk menjadi produk olahan adalah 0,01-0,2. Tujuan dari penelitian ini adalah mendapatkan rekayasa proses asetilasi untuk mendapatkan derajat substitusi 0,2 dan mengetahui perubahan karakteristik fisikokimia, hidrofobisitas dan kristalinitas pada pati dengan derajat substitusi 0,2. Jagung varietas Bisi-18 yang digunakan untuk penelitian berasal dari Kabupaten Bantul, Yogyakarta. Tahapan penelitian meliputi ekstraksi pati jagung dan modifikasi asetilasi dengan Rancangan Acak Kelompok. Faktor 1 adalah konsentrasi asetat anhidrat $(2,4,6 \%)$ dan faktor 2 adalah waktu reaksi $(5,10,15$ menit). Hasil penelitian menunjukkan bahwa proses asetilasi terjadi pada $\mathrm{pH}$ 8-8,4; suhu reaksi $28-30{ }^{\circ} \mathrm{C}$ selama 15 menit dengan konsentrasi asetat anhidrat $4 \%(\mathrm{v} / \mathrm{w})$ menghasilkan pati terasetilasi dengan derajat substitusi 0,2. Pati jagung tersebut mengalami perubahan karakteristik yaitu lebih hidrofob dan kristalinitas menurun. Pati terasetilasi dengan derajat substitusi 0,2 berpotensi untuk dijadikan bahan baku kue kering seperti cookies.
\end{abstract}

Kata kunci: Asetat Anhidrat, Derajat Substitusi, Kekompakan

\section{ABSTRACT}

Corn is one of the agricultural commodities with great potential to be developed commercially. Cookies from 100\% corn flour resulted in reduced consumer acceptance, caused by hard cookies. The hardness of the cookies from corn can also be caused by the low ability of starch to binding water and fat, and the compact structure of starch. One of the starch modification methods used to improve starch properties is acetylation. The degree of acetylation in starch that can be used to be a processed product is 0.01-0.2. The aims of this study were obtaining an acetylation process to obtain a degree of substitution of 0.2 and to determine the changes in the characteristics of physicochemical, hydrophobicity, and crystallinity of starch with a degree of substitution of 0.2. Corn variety Bisi-18 used for research comes from Bantul Regency, Yogyakarta. The research stages included extraction of corn starch and 
Jurnal Teknologi Pertanian Vol. 22 No. 2 [Agustus 2021] 101-108

Perubahan Karakteristik Fisikokimia, Hidrofobisitas dan Kristalinitas Pada Pati Jagung [Rosiana dkk]

modification of acetylation with a randomized block design. The first factor was the concentration of acetate anhydrous $(2,4,6 \%)$ and the second factor was the reaction time $(5,10,15$ minutes). The results showed that the acetylation process occurred at $\mathrm{pH} 8-8.4$; reaction temperature is $28-30^{\circ} \mathrm{C}$ for 15 minutes with $4 \%(v / w)$ acetate anhydrous to produce degree of substitution 0,2 acetylated corn starch. The characteristic of degree of substitution 0,2 acetylated corn starch is more hydrophobic and decreased crystallinity compared to natural starch. Acetylated starch with degree of substitution 0,2 has potential to be used as raw material for pastries such as cookies.

Keywords: Acetate Anhydrous, Degree of Substitution, Compactness

\section{PENDAHULUAN}

Cookies menjadi salah olahan pangan yang dikembangkan dari jagung. Pembuatan cookies dari tepung komposit (tepung terigu dan tepung jagung) masih disukai panelis berdasarkan penilaian sensoris. Ketika penggunaan tepung jagung ditingkatkan menjadi $100 \%$ maka terjadi penurunan penerimaan konsumen karena tekstur yang keras dan tidak renyah. Pembuatan kue kering dari campuran terigu, tepung jagung dan ubi kayu menunjukkan hasil semakin tinggi tepung jagung atau tepung ubi kayu maka tekstur semakin keras (Moeljaningsih, 2011). Pada pembuatan cookies dari tepung jagung harus ditambahkan mentega yang lebih banyak untuk menghasilkan cookies yang lebih lembut dan diterima oleh panelis (Bilgiçli et al., 2006). Modifikasi pati dapat digunakan untuk memperbaiki sifat tepung jagung. Umumnya, pada pembuatan cookies hanya menggunakan tepung jagung biasa atau jagung pregelatinisasi atau pati jagung ternikmatilasi (Bilgiçli et al., 2006; Hardiyanti et al., 2018; Irferamuna et al., 2019; Istinganah et al., 2017; Rai et al., 2014).

Struktur kompak, kuat dan kemampuan pati dalam mengikat minyak yang rendah merupakan penyebab dari tekstur cookies yang keras. Adonan yang yang terbentuk dari tepung jagung menjadi kurang elastis, maka tekstur cookies menjadi lebih keras. Oleh karena itu perlu dilakukan modifikasi pada pati jagung untuk menghasilkan pati jagung dengan sifat-sifat yang diinginkan.

Sifat baru yang diinginkan dari pati jagung terasetilasi yang dapat memperbaiki tekstur cookies adalah kristalinitas yang lebih rendah dan hidrofobisitas yang lebih tinggi. Sifat-sifat ini berhubungan erat derajat substitusi (DS). Pati dengan derajat substitusi 0,01-0,2 telah diterima oleh Food and Drug
Administration (FDA) untuk diaplikasikan pada makanan sebagai pengikatan, pengental, penstabil dan untuk memperbaiki tekstur (Chi et al., 2008; Getachew et al., 2020; Xu et al., 2004). Pati kentang terasetilasi dengan DS 0,185 dapat berasal dari konsentrasi asetat anhidrat $10 \mathrm{~g} / 100 \mathrm{~g}$, katalis $\mathrm{NaOH}$, waktu reaksi 60 menit pada suhu $25^{\circ} \mathrm{C}$ (Singh et al., 2004). Pati jagung terasetilasi dengan derajat substitusi 0,2 dihasilkan dari $3 x$ reaksi asetilasi dengan konsentrasi asetat anhidrat sebanyak $8 \%(\mathrm{w} / \mathrm{w})$ selama 60 menit dengan katalis $\mathrm{NaOH}$ (Ayucitra, 2012). Selain untuk memperbaiki karakteristik pati, pati terasetilasi juga memiliki peran sebagai prebiotik jika DS berkisar antara 0,2-0,25 (Annison et al., 2003). Pati terasetilasi dengan derajat substitusi 0,2 diharapkan dapat memperbaiki tekstur cookies atau produk sejenis dan memiliki peran sebagai prebiotik. Adapun tujuan dari penelitian ini yaitu mendapatkan rekayasa proses asetilasi untuk mendapatkan derajat substitusi 0,2 dan mengetahui perubahan karakteristik fisikokimia, hidrofobisitas dan kristalinitas pati terasetilasi.

\section{METODE}

Bahan-bahan yang digunakan pada penelitian antara lain Jagung varietas Bisi 18 dari Ds. Terong, Kec. Dlingo, Kab. Bantul. Enzim aamilase (Sigma), pepsin, dan amyloglukosidase. Bahan-bahan kimia seperti $\mathrm{NaOH}, \mathrm{HCl}, \mathrm{KOH}$, asetat anhidrat, natrium bisulfit, asam sulfat, garam rochele, aquades diperoleh dari Laboratorium Kimia dan Biokimia Pangan, Fakultas Teknologi Pertanian, Universitas Gadjah Mada.

Peralatan yang digunakan dalam penelitian di laboratorium antara lain waterbath (Shibata), inkubator (Memmert), Spektrofotometer (Spektronic), pH meter (Methrom), Laminar Air Flow (Labconco), 
Autoklaf, stirer, muffle, alat pengering, timbangan analitik, optilab, mikroskop, blender (Cosmos), sentrifuse, Fourier Transform
Infrared (FTIR) instrumen (Shimadzu), X-ray Diffaction instrumen, dan Texture Analyzer.

Tabel 1. Pengaruh jumlah asetat anhidrat dan waktu reaksi terhadap persen asetil dan derajat substitusi

\begin{tabular}{cccc}
\hline $\begin{array}{c}\text { Jumlah Asetat Anhidrat } \\
(\%)(\mathrm{v} / \mathrm{w})\end{array}$ & Lama reaksi (menit) & \%asetil & Derajat Substitusi \\
\hline 2 & 5 & $1,34 \pm 0,67^{\mathrm{a}}$ & $0,04 \pm 0,03^{\mathrm{a}}$ \\
& 10 & $2,48 \pm 0,68^{\mathrm{b}}$ & $0,09 \pm 0,02^{\mathrm{b}}$ \\
4 & 15 & $3,57 \pm 0,61^{\mathrm{c}}$ & $0,12 \pm 0,02^{\mathrm{bc}}$ \\
& 5 & $3,74 \pm 0,51^{\mathrm{c}}$ & $0,15 \pm 0,03^{\mathrm{cd}}$ \\
6 & 10 & $4,14 \pm 0,68^{\mathrm{cd}}$ & $0,16 \pm 0,03^{\mathrm{d}}$ \\
& 15 & $5,00 \pm 0,39^{\mathrm{d}}$ & $0,20 \pm 0,02^{\mathrm{e}}$ \\
& 5 & $6,32 \pm 0,09^{\mathrm{e}}$ & $0,26 \pm 0,01^{\mathrm{f}}$ \\
10 & $5,36 \pm 0,32^{\mathrm{d}}$ & $0,22 \pm 0,01^{\mathrm{e}}$ \\
& 15 & $5,30 \pm 0,39^{\mathrm{d}}$ & $0,21 \pm 0,07^{\mathrm{e}}$ \\
\hline
\end{tabular}

Data merupakan rerata tiga ulangan yang disajikan rata-rata \pm standar deviasi. Superskrip menyatakan berbeda nyata pada kolom yang sama berdasarkan ANOVA $(p<0,05)$

\section{Ekstraksi pati jagung}

$500 \mathrm{~g}$ biji jagung yang telah disortasi direndam dengan 1 liter larutan Na-bisulfit 0,2\% selama 36 jam. Biji jagung digiling kasar menggunakan blender dengan penambahan air $500 \mathrm{ml}$ pada kecepatan rendah selama satu menit. Kulit luar hasil penggilingan dipisahkan melalui pencucian. Penggilingan halus pada kecepatan tinggi dilakukan selama lima menit dengan penambahan air $200 \mathrm{ml}$. Pati diekstrak dengan menambahkan 3 liter air. Selanjutnya dilakukan penyaringan dengan kain kasa. Setelah pengendapan selama 4 jam diperoleh pati basah. Pemisahan pati dengan protein ditambahkan $100 \mathrm{ml}$ larutan $\mathrm{NaOH} \quad 0,1 \mathrm{~N}$, diaduk, kemudian diulangi pengendapan dengan 3 kali pencucian. Endapan dipisahkan kemudian dikeringkan pada suhu $50{ }^{\circ} \mathrm{C}$ selama 12 jam. Selanjutnya digiling dan diayak menggunakan ayakan 80 mesh (Suarni et al., 2013).

\section{Proses asetilasi}

Pelarutan $10 \mathrm{~g}$ pati jagung dalam $25 \mathrm{ml}$ aquades. Pencampuran dilakukan dengan stirer pada suhu ruang selama satu jam. Selanjutnya, $\mathrm{pH}$ diatur dengan menambahkan $1 \mathrm{~N} \mathrm{NaOH}$ menjadi $\mathrm{pH} 8$, kemudian ditambahkan asetat anhidrat sebanyak 2,4,6\% dari berat kering sampel. $\mathrm{pH}$ dipertahankan 88,4 . Waktu reaksi asetilasi dihitung setelah semua asetat anhidrat selesai ditambahkan. Reaksi asetilasi berlangsung selama 5, 10, dan 15 menit. Setelah waktu asetilasi selesai, reaksi dihentikan dengan menurunkan $\mathrm{pH}$ hingga 4,5 dengan penambahan $1 \mathrm{~N} \mathrm{HCl}$. Sisa reagen dihilangkan dengan mencuci sampel sebanyak $3 x$ dengan akuades. Selanjutnya, sampel dikeringkan pada suhu $50{ }^{\circ} \mathrm{C}$ selama 12 jam. Pati yang telah kering dihaluskan, diayak dengan pengayak 80 mesh dan disimpan (Singh et al., 2004).

\section{Analisa}

Analisa derajat substitusi (Singh et al., 2004), kadar amilosa (Apriyantono et al., 1989), analisa daya mengembang dan kelarutan (Satmawalati, 2011), analisa water and oil binding capacity (Yousif et al., 2012), analisa FTIR (Xu et al., 2004), analisa kristalinitas (x-ray diffraction) (Xu et al., 2004), gelatinisasi pati (Li et al., 2014).

\section{HASIL DAN PEMBAHASAN}

\section{Pengaruh Jumlah Asetat Anhidrat dan Waktu Reaksi Terhadap Persen Asetil dan Derajat Substitusi}

Pada proses ekstraksi pati, rendemen pati yang dihasilkan adalah $84,31 \%$ (db). Modifikasi dengan asetilasi dilakukan dengan mereaksikan pati jagung dengan asetat anhidrat sehingga terjadi penambahan gugus fungsional baru yaitu gugus asetil yang mengganti gugus hidroksil (-OH) pada pati. Persen asetil dan derajat substitusi disajikan pada Tabel 1.

Kenaikan persen asetil dan derajat substitusi terjadi seiring peningkatan jumlah 
asetat anhidrat yang ditambahkan dan semakin lama waktu reaksi. Jumlah asil tidak cukup untuk bereaksi dengan gugus hidroksil jika jumlahnya terlalu rendah. Waktu reaksi berkaitan dengan seberapa lama untuk terjadi reaksi asetilasi. Proses asetilasi bersifat non linier, pada waktu reaksi yang terlalu lama dapat menurunkan persen asetil dan derajat substitusi. Han et al. (2013) mengatakan benturan antara reagen dan pati rendah saat konsentrasi reagen rendah. Konsentrasi reagen yang tepat dapat memberikan kontak yang cukup bagi reagen dan pati untuk bertemu. Saat konsentrasi reagen ditingkatkan, maka akan terjadi hidrolisis pati sehingga reaksi esterifikasi tidak dapat berjalan dengan baik. Semakin lama waktu reaksi, reaktivitas gugus fungsional pada molekul pati dapat menurun sehingga kecepatan reaksi akan menurun pula. Selain itu dapat pula disebabkan oleh terjadi reaksi samping yakni reaksi antara natrium hidroksida dan asetat anhidrat menjadi natrium asetat sehingga menurunkan presentase asetil dan derajat substitusi (Xu et al., 2004). Selanjutnya pada penelitian ini menggunakan $4 \%(\mathrm{v} / \mathrm{w})$ asetat anhidrat dan waktu reaksi 15 menit dapat menghasilkan pati terasetilasi dengan derajat substitusi 0,2.

Analisa FTIR dilakukan dengan tujuan untuk melakukan konfirmasi proses asetilasi. Spektrum IR pada pati alami dan pati asetilasi ditunjukkan pada Gambar 1. Pati terasetilasi dijumpai gugus ester $(\mathrm{C}=\mathrm{O})$ pada peak pendek dengan panjang gelombang $1750-1735 \mathrm{~cm}^{-1}$, $1373 \mathrm{~cm}^{-1}$ yang menunjukkan ikatan $\mathrm{C}=\mathrm{O}$ dan gugus gugus $1242 \mathrm{~cm}^{-1}$ (ikatan $\mathrm{C}-\mathrm{C}$ ). Peningkatan derajat substitusi dapat ditunjukkan dengan peak yang tajam (Olagunju et al., 2020). Kisaran panjang gelombang $3450 \mathrm{~cm}^{-1}$ semakin melebar pada pati terasetilasi dengan derajat substitusi 0,2 dibandingkan dengan pati alami karena gugus hidroksil berkurang.

\section{Karakteristik Fisikokimia Pati Terasetilasi dengan Derajat Substitusi 0,2}

Asetilasi menyebabkan perubahan karakter fisikokimia pada pati alami. Perubahan ini diharapkan dimiliki oleh pati sehingga dapat diaplikasikan pada produk tertentu. Tabel 2 menunjukkan karakteristik pada pati asetilasi dengan derajat substitusi 0,2 . Amilosa pada pati terasetilasi dengan derajat substitusi 0,2 mengalami penurunan sebanyak dibandingkan dengan pati alami.

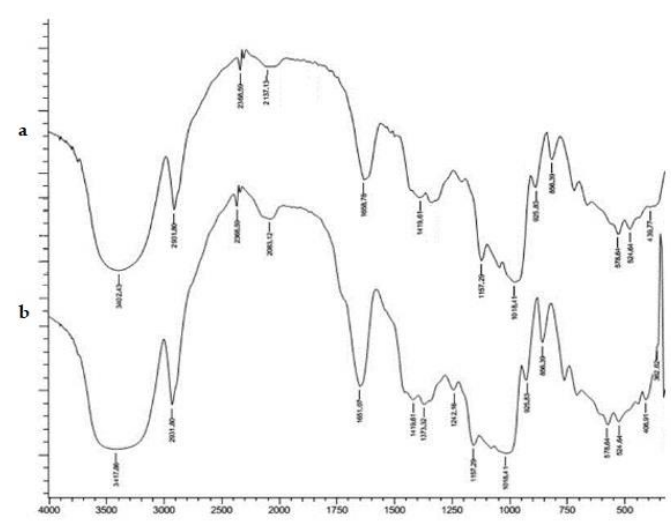

Gambar 1. Spektra IR pada pati alami (a) dan pati terasetilasi dengan derajat substitusi 0,2 (b)

Proses substitusi selama proses asetilasi berlangsung pada daerah amorf yang terdiri atas amilosa. Struktur pati berubah karena asetilasi melemahkan ikatan intermolekuler pada granula pati. Ikatan yang lemah ini dapat pula menyebabkan amilosa terlepas dari pati. Penurunan amilosa pada pati setelah proses asetilasi juga terjadi pada pati jagung, singkong dan kentang manis (Lawal et al., 2015). Sebaliknya, asetilasi juga dapat meningkatkan amilosa pada pati gude (Olagunju et al., 2020). Perubahan jumlah amilosa dan amilopektin setelah asetilasi menunjukkan perubahan formasi struktur sehingga berpengaruh pula terhadap ikatan amilosa-iodin saat analisa amilosa dilakukan (Lawal et al., 2015).

Tabel 2. Karakteristik pati terasetilasi dengan derajat substitusi 0,2

\begin{tabular}{lcc}
\hline Parameter & $\begin{array}{c}\text { Pati } \\
\text { Alami }\end{array}$ & $\begin{array}{c}\text { Pati } \\
\text { Asetilasi }\end{array}$ \\
\hline Amilosa (\%) & $33,44 \pm 0,36$ & $32,29 \pm 0,12^{*}$ \\
$\begin{array}{l}\text { Water binding } \\
\text { capacity (g/g) }\end{array}$ & $1,25 \pm 0,04$ & $1,01 \pm 0,02^{*}$ \\
$\begin{array}{l}\text { Oil binding capacity } \\
\text { (g/g) }\end{array}$ & $0,96 \pm 0,01$ & $1,14 \pm 0,02^{*}$ \\
$\begin{array}{l}\text { Daya mengembang } \\
\text { (g/g) }\end{array}$ & $9,89 \pm 0,09$ & $13,15 \pm 0,43^{*}$ \\
Kelarutan (g/g) & $0,31 \pm 0,01$ & $0,13 \pm 0,01^{*}$ \\
\hline
\end{tabular}

Data merupakan rerata tiga ulangan yang disajikan rata-rata \pm standar deviasi

$\left(^{*}\right)$ menyatakan berbeda nyata pada baris yang sama berdasarkan t-test $(\mathrm{p}<0,05)$ 
Water and oil binding capacity menunjukkan kemampuan pati untuk mengikat air dan minyak. Water binding capacity menurun dari $1,25 \mathrm{~g} / \mathrm{g}$ pada pati alami menjadi $1,01 \mathrm{~g} / \mathrm{g}$ pada pati asetilasi. Pada oil binding capacity mengalami peningkatan

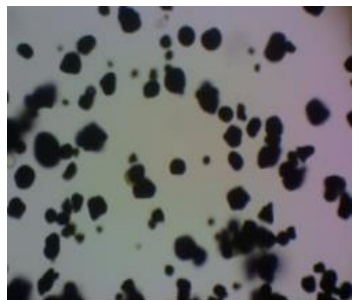

a

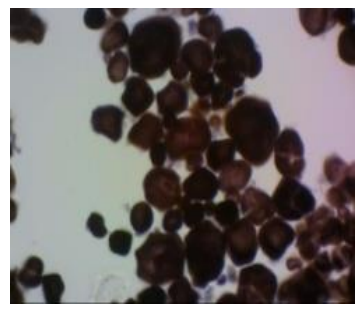

e

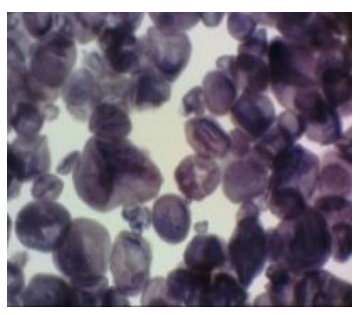

i

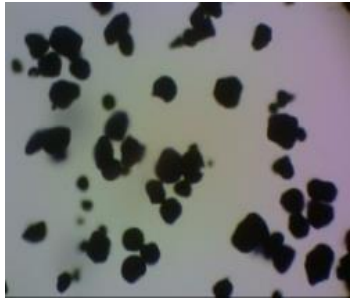

b

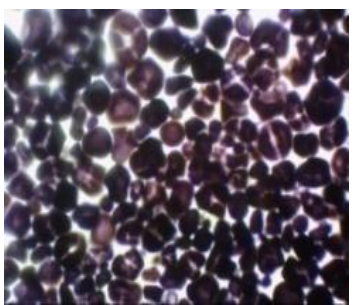

f

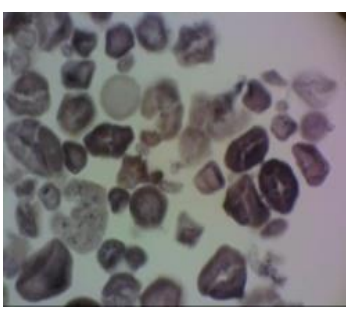

j

dari $0,96 \mathrm{~g} / \mathrm{g}$ dari pati alami menjadi $1,14 \mathrm{~g} / \mathrm{g}$ pada pati asetilasi. Gugus asetil yang bersifat hidrofob dapat menurunkan kemampuan mengikat air dan meningkatkan kemampuan mengikat minyak pada pati (Garg and Jana, 2011).

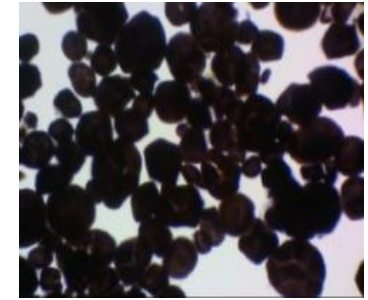

C

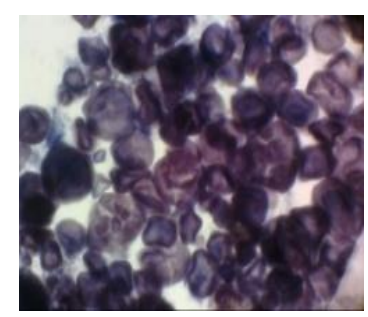

$\mathrm{g}$

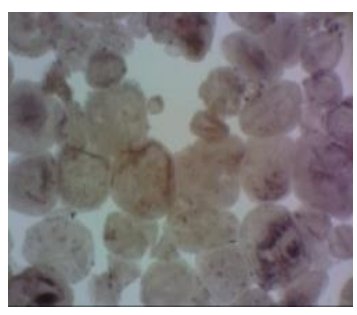

$\mathrm{k}$

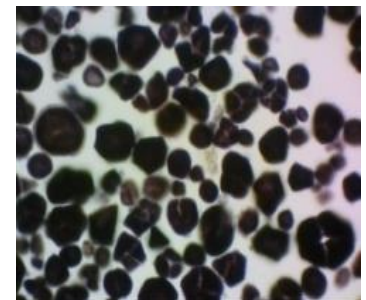

d

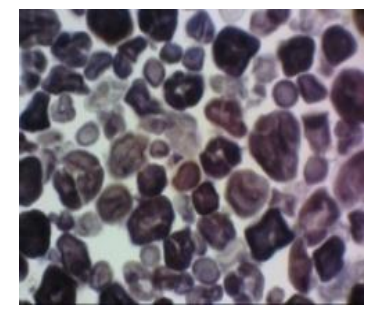

$\mathrm{h}$

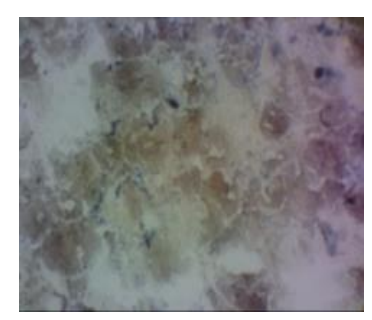

1

Gambar 2. Proses gelatinisasi pati alami dan pati terasetilasi dengan derajat substitusi 0,2 pada berbagai suhu. (a) pati alami; (b) pati terasetilasi; (c) pati alami pada suhu $70^{\circ} \mathrm{C}$, (d) pati terasetilasi pada suhu $70^{\circ} \mathrm{C}$; (e) pati alami pada suhu $75^{\circ} \mathrm{C}$; (f) pati terasetilasi pada suhu $75^{\circ} \mathrm{C}$; (g) pati alami pada suhu $80^{\circ} \mathrm{C}$; (h) pati terasetilasi pada suhu $80^{\circ} \mathrm{C}$; (i) pati alami pada suhu $85^{\circ} \mathrm{C}$; (j) pati terasetilasi pada suhu $85^{\circ} \mathrm{C}$; (k) pati alami pada suhu $90^{\circ} \mathrm{C}$; (l) pati terasetilasi pada suhu $95^{\circ} \mathrm{C}$

Terjadi peningkatan daya mengembang pati dari 9,89 g/g pada pati alami menjadi $13,15 \mathrm{~g} / \mathrm{g}$ pada pati asetilasi. Gugus asetil menggantikan gugus hidroksil mengakibatkan struktur lebih terbuka karena asetil akan menyebabkan gaya tolak menolak antara gugus yang berdekatan, sehingga akan menghambat interaksi antar rantai. Oleh karena itu memudahkan air masuk ke dalam struktur pati (Garg dan Jana, 2011; López et al., 2010). Kelarutan pati asetilasi menurun dari $0,31 \mathrm{~g} / \mathrm{g}$ pada pati alami menjadi $0,13 \mathrm{~g} / \mathrm{g}$ pada pati terasetilasi. Penurunan kelarutan pati jagung terasetilasi diduga karena terjadi kompleks ikatan yang sangat kuat antara amilosa dengan gugus subtituen sehingga pati dapat memerangkap air di dalam molekul pati (Siroha et al., 2019).

\section{Karakteristik Morfologi dan Gelatinisasi Pati Terasetilasi dengan Derajat Substitusi 0,2}

Perubahan struktur pada pati terasetilasi menjadi kurang kompak menyebabkan penurunan kestabilan terhadap panas dan suhu. Akibatnya suhu gelatinisasi menurun. Kompleks warna biru pada pati terjadi saat amilosa berikatan dengan iodin. Saat gelatinisasi, warna biru menghilang karena amilosa akan keluar dari granula pati sehingga tidak bisa lagi berikatan dengan iodin. Semakin tinggi suhu pemanasan, maka warna biru pada granula akan semakin memudar dan menghilang.

Tampak pada Gambar 2 bahwa pada suhu yang sama, jumlah pati yang tergelatinisasi pada pati terasetilasi lebih banyak dibandingkan pada pati alami. Suhu 
Jurnal Teknologi Pertanian Vol. 22 No. 2 [Agustus 2021] 101-108

Perubahan Karakteristik Fisikokimia, Hidrofobisitas dan Kristalinitas Pada Pati Jagung [Rosiana dkk]

gelatinisasi pada pati alami terjadi pada kisaran suhu $80{ }^{\circ} \mathrm{C}$ yang ditandai dengan pembengkakan maksimal granula pati. Pada suhu $90{ }^{\circ} \mathrm{C}$ amilosa telah terlepas semua sehingga granula berwarna putih. Proses gelatinisasi pati terasetilasi dengan derajat substitusi 0,2 lebih cepat dibandingkan dengan pati alami. Pada suhu $70{ }^{\circ} \mathrm{C}$ granula telah mengalami gelatinisasi awal.

Tabel 3. Intensitas peak pada pati alami dan pati terasetilasi dengan derajat substitusi 0,2

\begin{tabular}{lccccc}
\hline Jenis pati & No. & Peak No. & 2Theta(deg) & D (A) & Intensity (counts) \\
\hline Pati alami & 1 & 15 & 17.9800 & 4.92954 & 287 \\
& 2 & 14 & 17.1000 & 5.18119 & 257 \\
& 3 & 19 & 23.2368 & 3.82487 & 232 \\
\hline Pati asetilasi & 1 & 15 & 17.9200 & 4.94591 & 214 \\
DS 0,2 & 2 & 19 & 23.0916 & 3.84859 & 199 \\
& 3 & 14 & 16.9800 & 5.21753 & 196 \\
\hline
\end{tabular}

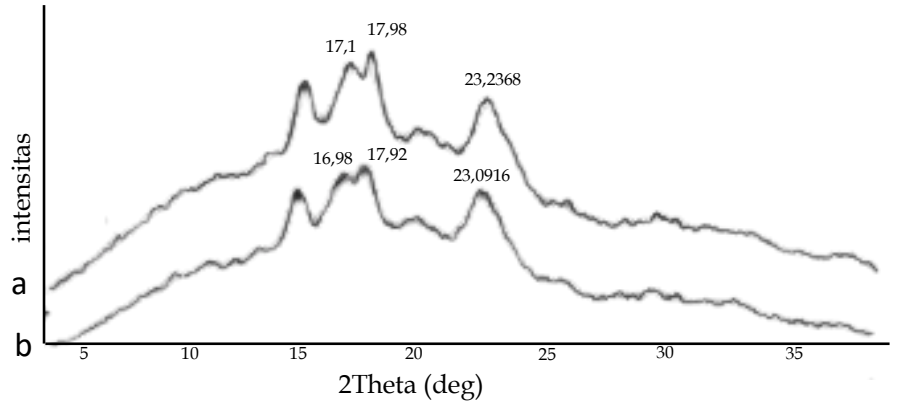

Gambar 3. Pola kritalinitas pada pati alami (a) dan pati terasetilasi DS 0,2 (b)

Pati mengalami pembengkakan yang lebih banyak dibanding pati alami yang ditandai dengan banyak granula yang mulai pecah. Puncak gelatinisasi pada pati terasetilasi pada suhu antara $75-80^{\circ} \mathrm{C}$. Pada suhu $80{ }^{\circ} \mathrm{C}$ tampak warna putih karena beberapa granula yang amilosanya terlepas. Bahkan pada suhu $90{ }^{\circ} \mathrm{C}$ granula pati asetilasi telah rusak. Kehadiran gugus asetil pada biopolimer meningkatkan fleksibitas struktur (Garg dan Jana, 2011; Han et al., 2012; Siroha et al., 2019).

Suhu puncak gelatinsisasi pati alami jagung berada pada suhu $72,8{ }^{\circ} \mathrm{C}$. Pada suhu puncak gelatinisasi pati terasetilasi yaitu $67,4{ }^{\circ} \mathrm{C}, 67,4{ }^{\circ} \mathrm{C}$ dan $63,3{ }^{\circ} \mathrm{C}$ dimiliki oleh pati asetilasi jagung yang memiliki derajat substitusi 0,071, 0,105, dan 0,133 (Han et al., 2012).

\section{Kristalinitas Pati Terasetilasi dengan Derajat Substitusi 0,2}

Analisa XRD dilakukan untuk menunjukkan sifat kristalinitas pati. Pati jagung alami memiliki jenis kristalinitas tipe A karena memiliki peak yang tajam pada $15^{\circ}, 17^{\circ}, 18^{\circ}, 23^{\circ}(2 \theta)$ (Chi et al., 2008). Kristalinitas tipe A pada pati jagung alami juga ditunjukkan kemunculan peak $2 \theta$ pada $15,8^{\circ}$ dan $23^{\circ}$ serta peak ganda pada $17,8^{\circ}$ dan $18,8^{\circ}$. Gambar 3 menunjukkan jenis kristalinitas pati alami adalah tipe A. Peak terkuat pada 17,98000, 17,10000, 23,23680 (20). Pati terasetilasi juga memiliki tipe kristalin tipe A dengan peak terkuat pada pati terasetilasi yaitu 17,92000, 23,09160, 16,98000 (20). Penurunan kristalinitas pati ditunjukkan dengan penurunan intensitas peak yaitu pada pati alami 287, 257, 232 menjadi 214, 199, 196 pada pati asetilasi (Tabel 3). Penurunan kristalinitas ini karena asetilasi dapat melemahkan ikatan intermolekuler pada granula pati. Selain itu penurunan kristalinitas menunjukkan bahwa asetilasi tidak hanya terjadi pada amilosa, namun juga pada amilopektin (Pietrzyk et al., 2018).

Semakin tinggi derajat substitusi maka struktur kristalin pada pati akan semakin menghilang. Pada pati jagung dengan derajat substitusi 0,85 memiliki bentuk kurva mirip dengan pati alami tapi 
muncul peak baru yaitu pada $9^{\circ}$ dan $20^{\circ}$ (20). Peak $9^{\circ}$ dan $20^{\circ}(2 \theta)$ pada pati jagung dengan derajat substitusi 1,78 dan 2,89 mengalami penajaman. Di sisi lain, terjadi penurunan peak pada $15^{\circ}, 17^{\circ}, 18^{\circ}$, dan $23^{\circ}$ (20) (Chi et al., 2008). Struktur kristalin yang menghilang juga terjadi pada pati kentang terasetilasi dengan derajat substitusi 1,83 ; 2,$03 ; 2,65$, dan 2,93. Tipe kristalinitas pati terasetilasi ini berubah dari tipe A menjadi tipe V (Diop et al., 2011).

\section{SIMPULAN}

Pati jagung terasetilasi dengan derajat substitusi 0,2 berlangsung pada $\mathrm{pH}$ 8-8,4; suhu reaksi $28-30{ }^{\circ} \mathrm{C}$, selama 15 menit dan konsentrasi asetat anhidrat $4 \%(\mathrm{v} / \mathrm{w})$. Perubahan pada pati terasetilasi yaitu penurunan kadar amilosa, kapasitas pengikatan air dan kelarutan serta peningkatan pada kapasitas pengikatan minyak dan daya mengembang. Penurunan kristalinitas pada pati terasetilasi ditandai oleh penurunan suhu gelatinisasi dan penurunan intensitas peak pada hasil analisa XRD. Analisa FTIR menunjukkan muncul gugus asetil baru. Pati terasetilasi dengan derajat substitusi 0,2 berpotensi untuk menjadi bahan baku produk kue kering seperti cookies.

\section{DAFTAR PUSTAKA}

Annison, -G., Illman, R, -J., Topping, D, -L., 2003. Acetylated, propionylated or butyrylated starches raise large bowel shortchain fatty acids preferentially when fed to rats. The Journal of Nutrition. 133, 3523-8. https://doi.org/10.1093/jn/133.11.3523

Apriyantono A, Fardiaz, D, Puspitasari, NL., Searnawati, Budiyanto, S. 1989. Analisis Pangan. IPB Press, Bogor

Ayucitra, -A., 2012. Preparation and characterisation of acetylated corn starches. International Journal of Chemical Engineering and Applications. 3, 156-159. http://dx.doi.org/10.7763/IJCEA.2012.V3 .178
Bilgiçli, -N., Kara, -M., Elgün, -A., Ertaş, N., Demir, M, -K., 2006. Determination of technologic and sensory properties of cookies prepared with corn flour. Journal of Food Agriculture and Environment. 4(2), 109-111. https://www.researchgate.net/public ation/235799904_Determination_of_te chnologic_and_sensory_properties_of_ cookies_prepared_with_corn_flour

Chi, -H., Xu, -K., Wu, -X., Chen, -Q., Xue, D., Song, -C., Zhang, -W., Wang, -P., 2008. Effect of acetylation on the properties of corn starch. Food Chemistry. 106, 923-928. https://doi.org/10.1016/j.foodchem.2007.07 .002

Diop, C, I, -K., Li, H, -L., Xie, B.J., Shi, J., 2011. Effects of acetic acid/acetic anhydride ratios on the properties of corn starch acetates. Food Chemistry. 126, 1662-1669. https://doi.org/10.1016/j.foodchem.2010.12 .050

Garg, -S., Jana, A, -K., 2011. Characterization and evaluation of acylated starch with different acyl groups and degrees of substitution. Carbohydrate Polymers. 83, 1623-1630. https://doi.org/10.1016/j.carbpol.201 0.10 .015

Getachew, -A., Yilma, -Z., Abrha, -S., 2020. Acetylation and evaluation of taro boloso-i starch as directly compressible excipient in tablet formulation. Advances in Pharmacological and Pharmaceutical Sciences. 2020, 1-10. https://doi.org/10.1155/2020/2708063

Han, -F., Gao, -C., Liu, -M., Huang, -F., Zhang, -B., 2013. Synthesis, optimization and characterization of acetylated corn starch with the high degree of substitution. International Journal of Biological Macromolecules. 59, 372-376. https://doi.org/10.1016/j.ijbiomac.2013. 04.080

Han, F., Liu, M., Gong, H., Lü, S., Ni, B., Zhang, B., 2012. Synthesis, characterization and functional properties of low substituted acetylated corn starch. International Journal of Biological Macromolecules. 50, 1026-1034. https://doi.org/10.1016/j.ijbiomac.2012. 02.030 
Hardiyanti., Kadirman., Rais, -M., 2018. Pengaruh substitusi tepung jagung (zea mays L.) dalam pembuatan cookies. Jurnal Pendidikan Teknologi Pertanian. 2, 123. https://doi.org/10.26858/jptp.v2i2.5167

Istinganah, -M., Rauf, -R., Widyaningsih, E, -N., 2017. Tingkat kekerasan dan daya terima biskuit dari campuran tepung jagung dan tepung terigu dengan volume air yang proporsional. Jurnal Kesehatan. 4, 109-111. https://doi.org/10.23917/jk.v10i2.5537

Lawal, M, -V., Odeniyi, M, -A., Itiola, O, A., 2015. Material and rheological properties of native, acetylated, and pregelatinized forms of corn, cassava, and sweet potato starches. Starch. 67, 964-975. https://doi.org/10.1002/star.201500044

Li, -Q., Xie, -Q., Yu, -S., Gao, -Q., 2014. Application of digital image analysis method to study the gelatinization process of starch/sodium chloride solution systems. Food Hydrocolloids. 35, 392-402. https://doi.org/10.1016/j.foodhyd.2013.06.017

López, O, -V., Zaritzky, N, -E., García, M, -A., 2010. Physicochemical characterization of chemically modified corn starches related to rheological behavior, retrogradation and film forming capacity. Journal of Food Engineering. 100, 160-168. https:// doi.org/10.1016/j.jfoodeng.20 10.03.041

Moeljaningsih., 2011. Kajian tentang penggunaan tepung jagung pada pembuatan kue kering. Berita Litbang Industri. 56, 30-35. http://lib.kemenperin.go.id/neo/downloa d_artikel.php?id=54

Olagunju, A, -I., Omoba, O, -S., Enujiugha, V, -N., Wiens, R, -A., Gough, K, -M., Aluko, R, -E., 2020. Influence of acetylation on physicochemical and morphological characteristics of pigeon pea starch. Food Hydrocolloids. 100, 105424. https://doi.org/10.1016/jfoodhyd.2019.105424

Pietrzyk, -S., Fortuna, -T., Juszczak, -L., Gałkowska, -D., Bączkowicz, -M., Łabanowska, -M., Kurdziel, -M., 2018. Influence of amylose content and oxidation level of potato starch on acetylation, granule structure and radicals' formation. International journal of biological macromolecules. 106, 57-67. https://doi.org/10.1016/j.ijbiomac.2017. 07.177

Rai, -S., Kaur, -A., Singh, -B., 2014. Quality characteristics of gluten free cookies prepared from different flour combinations. Journal of Food Science and Technology. 51, 785-789. https://doi.org/10.1007/s13197-0110547-1

Satmawalati, MEM., 2011. Karakteristik Tapioka Hasil Oksidasi dengan Variasi Kandungan Ozon Terlarut dan Konsentrasi Slurry Pati. Universitas Gadjah Mada, Yogyakarta

Singh, -N., Chawla, -D., Singh, -J., 2004. Influence of acetic anhydride on physicochemical, morphological and thermal properties of corn and potato starch. Food Chemstry. 86(4), 601-608. https://doi.org/10.1016/j.foodchem.2 003.10 .008

Siroha, A, -K., Sandhu, K, -S., Kaur, -M., Kaur, -V., 2019. Physicochemical, rheological, morphological and in vitro digestibility properties of pearl millet starch modified at varying levels of acetylation. International Journal of Biological Macromolecules. 131, 1077-1083. https://doi.org/10.1016/j.ijbiomac.2019. 03.179

Suarni, Firmansyah, I, -U., Aqil, -M., 2013. Keragaman mutu pati beberapa varietas jagung. Jurnal Penelitian Pertanian Tanaman Pangan. 32(1), 50-56. http://dx.doi.org/10.21082/jpptp.v32n1. 2013.p50-56

Xu, -Y., Miladinov, -V., Hanna, M, -A., 2004. Synthesis and characterization of starch acetates with high substitution. Cereal Chemistry. 81, 735-740. https://doi.org/10.1094/CCHEM.200 4.81.6.735

Yousif, E, -I., Gadallah, M, G, -E., Sorour, A, -M., 2012. Physico-chemical and rheological properties of modified corn starches and its effect on noodle quality. Annals of Agricultural Sciences. 57(1), 19-27. https://doi.org/10.1016/j.aoas.2012.03.008 